\title{
Strengthening the Culture of Democracy and Human Rights to Prevent Conflicts and Wars
}

\author{
Ziad Tak (PhD) \\ Beirut Arab University, Lebanon
}

Doi:10.19044/esj.2019.v15n11p19～ＵRL:http://dx.doi.org/10.19044/esj.2019.v15n11p19

\begin{abstract}
This paper focuses on investigating the relationship between democracy and the respect for human rights, to underpin the culture of human rights, and to establish democratic societies that enable individuals and groups to treat their conflicts by the use of peaceful methods. Therefore, the focus of this paper is to produce suggestions and solutions for enhancing and consolidating democracy, to be more integrated into the three main pillars of the United Nations (Peace and Security, Human Rights, and development), and to consider democracy as a fundamental right. Our research is based on a historical and empirical study which proved that a significant relationship exists between Human rights violation and conflicts.
\end{abstract}

Keywords: Democracy, Peace, Conflicts, Human Rights, Civil Society

\section{Introduction}

Democracy is a political government carried out either directly by the people or by means of their elected representatives. It is characterized by the independence powers of each other (legislative, executive, and judiciary), freedoms, political pluralism, fair elections, human rights, etc. Thus, without it (democracy), we do not have a good governance (Titilayo, 2006). The political experience has shown that democracy, as a product of the Western mind, is the highest political-constitutional formula for building modern states based on the recognition of human rights and freedoms (Théron \& Mourgeon, 1979).

\section{How?}

First, good governance is the cornerstone of transparency, integrity, honesty, loyalty, and commitment to genuine profit of humanity. The appreciation of one's own human rights and those of others, the determination to enforce them, and the regular evaluation and accountability of government through regular fair elections are the pre-requisite for the nurturing of democracy. 
Second, democracy is one of the universal core values and principles of the United Nations. Respect for human rights and essential freedoms, and the principle of holding periodic and genuine elections by universal suffrage, are the main elements of democracy. These values are embodied in the Universal Declaration of Human Rights in 1948. It was further developed in the International Covenant on Civil and Political Rights which enshrines a host of political rights and civil liberties underpinning meaningful democracies.

\section{I.}

\subsection{Main Underpinnings of Democracy}

The essential democratic underpinnings are human rights, fundamental freedoms, the equal rights of women and men, self-determination, and the removal of discrimination on the basis of race, sex, or religion (Khodor, 1997).

Democracy, based on the rule of Law, is ultimately a means to achieve international peace and security, economic and social progress, and respect for human rights. Thus, we deduce that democracy needs strong, accountable, and transparent institutions of governance which is based on the rule of law. Also it constitutes an accountable executive, an effective legislature, and an independent and impartial judiciary.

Consequently, the following principles are the main pillars and the underpinnings of democracy:

\section{Pluralism and Electoral Process}

The elections in each state have to be free and fair, without restriction and impediments in the electoral process.

\section{Free Government}

The elected representatives in the government have to be free from the influence of the military and the security services. Moreover, the religious and other powerful groups should not exercise political power and pressure on the representatives.

\section{Freedom of Expression}

The citizens have to feel free to form organizations, discuss about public issues, protest (with banning of violence), worship publicly and privately, etc.

\section{Respect for Human Rights}

All citizens must be treated equally under the law by considering gender equality, avoid the significant discrimination, enjoy basic security, etc. Therefore, the government should spread the perception of human rights to the population, where good governance has to provide and foster the culture of peace based on human rights. 


\section{- $\quad$ The Relationship between Human Rights and Conflict}

Violent conflict invariably leads to severe violations of human rights. Therefore, preserving human rights is generally essential for making peace, and making peace is essential for preserving human rights. Thus, violation of human rights is not only a result of war, but can also be a cause of it.

Numerous causes have led to the conflicts, including issues such as violations, economic decline, unemployment, poverty, the concentration of wealth in the hands of autocrats who has been in power for decades, insufficient transparency of its redistribution, corruption, and especially the refusal of the youth to accept the current situation. The issue of the Arab national state is an old matter that arose during the colonialism. The brisk transformation from civil to military regimes was under the subterfuge of victory for Palestine after the defeat of the Arab regimes in 1967. Militarism has penetrated into some Arab countries to take power which caused the collapse of the internal system (El Sayed, 2017). The civil state must be saved in the Arab world, which suffers from a breakdown and collapse as a result of weakness in its systems, the regional and international intervention, and its incapability to restore stability and sovereignty. During Arab Spring, there were hopes that the popular movements would end corruption, increase political participation, and result in economic equity. Thus, the series of protests across the Middle East and in North Africa that commenced in 2010 became known as the "Arab Spring" (Hardy, 2011). The world watched the events of the Arab Spring clearly, "gripped by the narrative of a young generation peacefully rising up against oppressive authoritarianism to secure a more democratic political system and a brighter economic future."

Human Rights can be good for resolving conflict. Thus, the question is: what is the role of human rights in resolving conflict?

Human rights can contribute to the long-term stability of a conflict settlement. The effective protection of human rights is usually correlated with justice. This is because in a just society, human rights will be protected. Citizens, the world community, and political leaders tend to accept solutions they view as just. Thus, a political settlement entrenched in human rights can help make solutions more durable. Human rights informed approach can also contribute to identifying the root causes of the conflict and potential means for addressing them (Packer, 2000). In consequence, conflict resolution and human rights complement each other.

\section{- Do International Human Rights Treaties Improve Respect for Human Rights?}

After the non-binding Universal Declaration of Human Rights, many international and regional human rights treaties have appeared. The findings pointed out that rarely does treaty ratification have unconditional effects on 
human rights. Conversely, in very totalitarism regimes with weak civil society, ratification can be expected to have no effect and is sometimes associated with rights violation. In the absence of democracy and a civil society, treaty ratification has no effect and is possibly even related to more human rights violations.

In consequence, for treaty ratification to work, there has to be conditions for parties, individuals, and civil society to persuade, convince, and pressure governments into translating the formal promise of better human rights protection into actual reality. We believe that ratification of human rights treaties improves respect for human rights, conditional on the extent of democracy and the strength of civil society.

\section{- Democracy Implementation and Different Cultures}

Contemporary democracy has started to grow since the beginning of the nineteenth Century, and it has gradually spread throughout the world as a civilize alternative to dictatorial regimes (Hussein, 2011). If allowed to work, democracy would bring a new way of life to many who have been oppressed. However, individual countries around the world must be able to implement its own version of government and social structure that suits its culture and belief. This should be done with adherence to granting equal rights and opportunities to all citizens, and the respect of human rights which are universal and not fragmented. Democracy works differently in different cultures. Hence, this is why western style democracy does not necessarily work in another area. This is because they do not know what to expect about setting up their own democracies in ways that suit their needs to build an alternative stable government.

Therefore, it is necessary to restore tranquility in religion by not allowing religious movements to attain power, as it has happened in some regions. We must form good states that are not based on extremism, terrorism, and violent phenomena under the name of religion. This can be achieved by rehabilitating the religious institution to confront these phenomena. The extremist should understand that he is part of the world and this is not done by clerics alone but by all sectors of society, intellectuals, media professionals, and academics. Religious institutions should not have influence on the aspects of social life or authority in the form of religion that people learn at school and hear in sermons. This is because economic development and religious extremism cannot coexist properly and may result to poverty. We should maintain an adaptive policy that takes into account local history and traditions as well as the legitimacy that are still inherent in the various governments, including most of the monarchies. In states where there are no pluralism, the United Nations can promote relations that are more just between the ruler and the ruled. This may open a path toward stable democracy (Abrams, 2016). 
Democracy has proved in repeated experiments, since the French Revolution to this day, that it is the best system that human has known morally, politically, and economically. Thus, if autocratic regimes return to power somewhere, democracy as a system and philosophy will become stronger than before (Macey \& Miller, 1993).

\section{- $\quad$ The Human Rights Performance in the Society}

Human rights performance is not easily measurable. We will distinguish between civil rights and personal integrity rights. Civil rights typically refer to such rights as the freedom of assembly and association, the freedom of speech, and the freedom of religious expression. Personal integrity rights typically refer to such rights as freedom from torture, freedom from unlawful and political imprisonment, freedom from unlawful physical or other harm, freedom from cruel and inhumane treatment, and the right to a fair trial. Personal integrity rights violations are more difficult to justify and are less subject to the relativist challenge. Civil rights violations do not carry quite the same status. As our measure of personal integrity rights, we use data from the two Purdue Political Terror Scales (PTS). One of the two PTS is based on a codification of country information from Amnesty International's annual human rights reports to a scale from 1 (best) to 5 (worst). Analogously, the other scale is based on information from the U.S. Department of State's Country Reports on Human Rights Practices (Neumayer, 2005).

\begin{tabular}{|l|l|l|l|}
\hline Level & Imprisonment for people's views & Torture & Political Murder \\
\hline 1 & People are not imprisoned & Rare or exceptional & Extraordinarily rare \\
\hline 2 & Limited amount of imprisonment & Exceptional & Rare \\
\hline 3 & $\begin{array}{l}\text { Extensive political imprisonment \& } \\
\text { unlimited detention }\end{array}$ & Common & Common \\
\hline 4 & $\begin{array}{l}\text { Extended political imprisonment \& } \\
\text { detention }\end{array}$ & Common & Common \\
\hline 5 & $\begin{array}{l}\text { No limits to pursue personal or ideological } \\
\text { goals }\end{array}$ & Extended violence & Extended violence \\
\hline
\end{tabular}

Table 1.

1. Countries under a secure rule of law (The best).

5. The leaders of these societies place no limits on the means or thoroughness with which they pursue personal or ideological goals (The worst).

\section{- The Classification of the Democratic States}

Democracy can be considered as a set of practices and regulations that protect freedom. The essential features of a democracy include government based on majority rule, political pluralism, the existence of free and fair elections, the protection of minorities, and respect for human rights. At present, the best known measures of democracy are the political freedom and 
civil liberties, electoral democracy based on a competitive and multiparty political system, secret ballots, etc. (Kekic, 2006). The correlation between democracy and development is debatable, and economic development does not lead to democracy (Horowitz, 2006). For example, China has taken the opportunity not only to step up internal repression, but also to export its strong influence to other countries which are copying its behavior and disdaining for democracy. Russia and China consider democracy as a threat to their repressive regimes. They work to undermine their institutions and play the role of spoiler, underpinning their positions by decreasing their adversaries.

\section{How to Classify the States according to their Democracy Level?}

Democracy faced its most serious crisis in the last decade, as its basic principles and tenets came under attack around the world ("Democracy in an age of anxiety: A report by the Economist Intelligent Unit". London: Economist Intelligence Unit: Democracy Index 2015). The right to choose leaders in free and fair elections, freedom of the press, and the rights of minorities are under assault and in retreat. This is the main source of the unrests in the Arab region. The classification of the democratic states is mainly based on the level of civil liberties and political rights which deteriorated to their lowest point for more than a decade (Abramowitz, 2018).

Full democracies are nations where civil liberties and basic political freedoms are not only respected, but are also reinforced by a political culture conducive for the prosperity of democratic principles. These nations have a valid system of governmental checks and balances, independent judiciary whose decisions are enforced, governments that function adequately, and various free media.

Flawed democracies are nations where elections are free and fair and basic civil liberties are respected but may have issues, for example media freedom infringement. Nonetheless, these nations have significant faults in other democratic aspects, including underdeveloped political culture, low levels of participation in politics, and issues in the functioning of the government.

Hybrid regimes are nations where consequential irregularities exist in elections regularly and, thus, preventing them from being fair and free. These nations have governments that apply pressure on political opponents, nonindependent judiciaries, corruption, pressure placed on the media, anemic rule of law, more pronounced faults than flawed democracies in the realms of underdeveloped political culture, low levels of participation in politics, and issues in the functioning of government.

Authoritarian regimes are nations where political pluralism has disappeared or is extremely limited. These nations are often under absolute dictatorships and may have some conventional institutions of democracy but 
with meager significance. Contraventions and abuses of civil liberties are common, elections are not fair and free, media is often submitted or controlled by groups allocated with the ruling regime, the judiciary is not independent, the presence of omnipresent censorship, and suppression of governmental criticism.

The chart below (Figure 1) indicates the number of Full democracies, Flawed democracies, Hybrid regimes, and Authoritarian regimes in 2018:

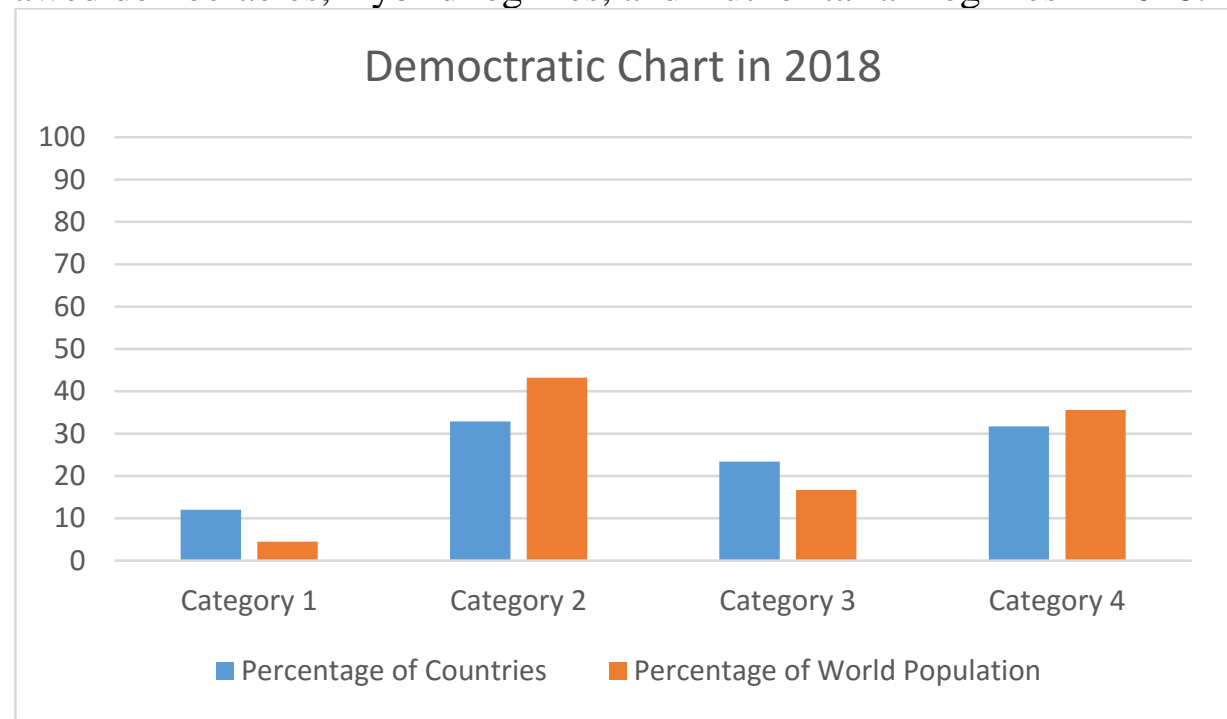

Figure 1

The important findings of the democracy index are:

- $4.5 \%$ of the world's people live in a full democracy.

- 42 countries experienced a decline in their index score compared with 89 in 2017, and 48 countries have improved their score.

- The Index notes that serve as threats to democracy around the world have become increasingly noticeable.

- $\quad$ The Impact of the Arab Unrests on Human Rights as one of the Main Pillars of Democracy

A truly democratic system includes a variety of checks and balances that ensure freedom and resilience over time, such as a free press, legal protections for minorities, independent judiciary, a strong opposition, and unfettered civil society groups. While the democratic world stood aside throughout the year, a coalition of repressive dictatorships shelled many countries, and the grinding violence has killed thousands of people and displaced millions more. Perhaps the most significant factor of the Arab Spring is the Syria crisis which has continued to escalate and become more complex, involving numerous proxy powers. For example, Russia intervened for many reasons, 
first of all was the desire to keep economic and political ties with Syria, dating before the cold war. In Syria, Russia was anxious to keep its naval base on the Syrian shore. However, there was also a political reason related to the fear of the spread of chaos in Russia, by seeing a kind of fundamentalist Sunni axis that would rise to areas populated by Muslims, not only Chechnya, but also Dagestan. For example, many Chechen jihadists, who have been fighting Russia for years, are also present in the Syrian fundamentalist militias (Daesh \& Al-Nusra, 2017).

The Syrian crisis led to an unprecedented hitting of Europe. The number of first time asylum applicants in Germany increased from 442 thousand in 2015 to 722 thousand in 2016. Greece and Italy also reported large increases (both in excess of 30 thousand additional first time asylum applicants) between 2015 and 2016. In relative terms, the largest increases in the number of first time applicants were recorded in Croatia (over 15 times as high), Slovenia (nearly five times as high), and Greece (more than four times as high). By contrast, the Netherlands, Slovakia, Austria, Denmark, Finland, Belgium, Hungary, and Sweden reported less than half the number of first time refuge applicants in 2016 as in 2015; Norway also recorded a large fall (The Economist Intelligence Unit's democracy index: The retreat of global democracy stopped in 2018 . January, 8, 2019).

Arrivals of refugees to Europe declined in 2016, largely due to the stiffening of borders in the Balkans and an agreement between the EU and Turkey to block irregular departures. According to the United Nations High Commissioner for Refugees (UNHCR), about 8,000 migrants between April and July 2016 after the agreement with Turkey was put into full effect. Before the agreement, about 150,000 migrants had arrived in Greece between January and March 2016. In response, affected countries seek to regain control by putting in place heavy security measures along the borders of the Balkan countries. The creation of these new obstacles did not reduce the flow: it only redirects it towards new and more dangerous routes. Thus, this is the case over the sea between January and May 2016. Since 2015, more than 1,224,000 migrants have arrived in Europe, and the majority of them are fleeing conflicts in Syria, Iraq or Afghanistan. However, the drop in numbers failed to stop the anti-refugee rhetoric, as European political leaders routinely smeared those fleeing conflict zones as criminals, rapists, and terrorists (Puddington \& Roylance, 2017).

Consequently, the crisis and unrests in the middle east and north Africa have deterred a huge number of children from the basic education and youth to complete their study. This situation leads to a big problem for the next generation. This was represented by the misunderstanding of basic human rights, increasing poverty, and the youth still practice apathy which weaken democracy and awake the upheavals and revolutions. There is a reciprocal 
relationship between unbearable economic inequality and war. Thus, war causes poverty and poverty causes war (Avery, 2009). Poverty threatens people's well-being directly and serves as the breeding ground for other threats.

\section{Conclusion}

Generally, war and conflict are related to the totalitarian regimes. Thus, the transformation of States into a democratic system would eliminate the phenomenon of war and conflict without being influenced by the personality of the leader. Contemporary research on democracy and conflict began with the observation that democracies are less likely to fight each other than other types of regimes (Gibler, 2016). The four pillars of democracy (Electoral process and pluralism, Free government, Freedom of expression, and Respect for Human rights) are all interconnected. Thus, we cannot fully achieve one without achieving all of them. I personally believe that impediments to reform and make progress will not be allowed to hinder our efforts.

Many other studies have shown that many people may become soldiers for directly less material reasons. This stems from despair to a whole range of socio-emotional motivations such as grief, anger, pride in participation, or to gain a new sense of hope and dignity. While poverty, social exclusion, inequality, discrimination and other sources of grievances exist in most societies, only a handful of countries have experienced civil wars. This is because not all countries have in place appropriate structures and institutions that allow the translation of grievances into acts of violence and rebellion (Justino, 2011). There is another important influence of ideology in conflicts. It may be used to rally the masses behind a certain goal, which was what Hitler did when his party adopted the Nazi fascist ideological party and sought to inflame the eagerness of the masses and push them into World War II. Brzezinski, the former US national security adviser, pointed out that most of the victims of the past century have fallen victim to the blind enthusiasm of what he called beyond myth, which means the absolute conviction of the ideologies that led people to the worst fate. Therefore, we must consider democracy to be a right, not a blind ideology, because the democratic principles are now emerging as international principles that must be respected by all.

History and investigation have proven that the following recommendations lead to democracy in each society:

a. Popular participation, collective deliberation, and political equality. 
b. Democracy is a reflection of self-determination and must be based on the freely expressed will of the people, both women and men.

c. Women's full and effective participation and equal opportunities for leadership at all levels of decision-making in economic, political, and public life. Furthermore, promoting women's rights is an integral and essential part of democracy. This includes addressing gender discrimination that contributes to women's exclusion and the marginalization of their roles. Therefore, we must support new democracies in improving gender responsiveness in the elections and promote women's political participation. For example, the Arab Spring has brought a set of enormous challenges to the region, but it also created some hope for women's political empowerment. Algeria has compelled a mandatory party quota in 2012, and women now constitute 30 percent of the Algerian Parliament.

d. Based on respect for all human rights, the rights, indigenous peoples, children, vulnerable, disadvantaged and unpopular groups or individuals must be safeguarded.

e. The development of a culture of democracy is essential to help to inculcate democratic values and principles in a society. It also helps in encouraging citizens to be informed of their rights and the laws and policies designed to protect them.

f. Education for democracy should begin with the young in order to promote democratic values and principles at an early stage. Education is considered as a driver for development and the reduction of poverty in these societies. It creates a path to a better health, peaceful and democratic societies. For example, USAID seeks to provide access to education during crisis and conflict which negatively affect the education of children by providing safe learning opportunities for students and teachers, especially for the most vulnerable. In addition, USAID prevents and mitigates conflict and crisis through conflict sensitive education programs, community engagement and disaster - risk reduction activities.

g. Political parties play an essential role in democracy by aggregating interests and integrating citizens into the political process. Therefore, democracy requires a political pluralism and plays a role in governance through periodic and genuine elections.

h. Transparency and access to information about public affairs must be guaranteed. States should be encouraged to adopt and 
implement legislation ensuring broad access to information by the public. To accomplish these goals requires e-governance whereby relevant information and public services can be provided to citizens instantaneously.

i. Ensure the freedom of Media to perform its fundamental role. We have not forgotten the influence of Media in the socialization and education of children and young people to promote the values of reverence for human rights and democracy. In particular, this also involves avoiding programs and other products that incites hatred, violence, cruelty, and disrespect for human dignity.

j. An active role is essential for non-governmental organizations and democratic reform groups, women's groups, human rights groups, social movements, minority representatives, and others. Such groups have an important contribution to the formulation, advocacy, and defense of democratic rights.

I truly believe that strengthening democracy is essential for preventing abuse of the rule of law and human rights. Moreover, democratic governance is crucial to the advancement of human development and the realization of human rights.

\section{References:}

1. Abrams Elliott (2016). "How to support Democracy in The Arab world". New York: Council on Foreign Relations.

2. Abramowitz, M. (2018). "Freedom in the world 2018, Democracy in crisis". Freedom House. http: www.freedomintheworld.org

3. Avery, J. (2009). Crisis 21 "Civilization's crisis in the $21^{\text {st }}$ century". University of Copenhagen.

4. "Democracy in an age of anxiety: A report by the Economist Intelligent Unit". London: Economist Intelligence Unit: Democracy Index 2015. http:www.economist.com/media/pdf/DEMOCRACY_INDEX

5. "Education in crisis and conflict", USAID education. http: www.usaid.gov/education.

6. El Sayed Radwan (2017). "The current situations in Lebanon and Arab problems." Paper presented at Beirut Arab University North Alumni conference. Tripoli.

7. Eurostat Statistics Explained, “Asylum Statistics", March 2017. http:// ec.europa.eu/eurostat/statisticsexplained/index.php/Asylum_statistics.

8. Gibler, D.,P. (2016). Democracy and Conflict, Oxford bibliographies. DOI: $10.1093 / \mathrm{OBO} / 9780199743292-0183$ 
9. Hardy, R. (2011). "Egypt protests: an Arab spring as old order crumbles". BBC News, February 2, 2011. http: www.bbc.com/news/world-middle-east-12339521.

10. Horowitz, I. (2006). "The struggle for Democracy." The National Interest Magazine, Spring 2006. http: //nationalinterest.org/article/thestruggle-for-democracy-880.

11. Hussein, K. (2011). International Relations, Theory, actually, persons and Issues. Beirut: Al-Halabi Legal Publications, $1^{\text {st }}$ edition.

12. Justino, P. (2011). "Conflict Traps: How does poverty cause war, and how does war cause poverty?" MICROCON. https://microconflict.wordpress.com/.../conflict-traps.

13. Kazamias, A. (2011). "The Anger Revolutions in the Middle East: an answer to decades of failed reform". Balkan and Near Eastern Studies 13:2. P.143-156. DOI: 10.1080/19448953.2011.578857

14. Kekic, L. (2006). "The Economist intelligence unit's index of democracy". London: Economist Intelligence Unit, (2006, November 15). www.economist.com/media/pdf/DEMOCRACY_INDEX

15. Khodor, K. (1997). Introduction to the public freedoms and human rights. Tripoli: The new Institution for Book. Korotayev, A. \& Zinkina, J. (2011).

16. Law No.12 of January 12, 2012 stipulated that political parties should include female candidates on their party lists according to the size of the constituency.

17. Macey, J. \& Miller, G. (1993). "The end of history and the new world order: The triumph of capitalism and the competition between Liberalism and Democracy". Cornell International Law journal, (vol. 48, no. 1). https://scholarship.law.cornell.edu/cilj/vol25/iss2/1.

18. Maietta, M. (2016). "The European Refugee Crisis: forecasting for 2018". Humanitarian Alternatives 3.

19. Neumayer, E. (2005). "Do international human rights treaties improve respect for human rights?". Journal of conflict resolution, (Vol.49 (6). P. 934-935. DOI: 10.1177/0022002705281667).

20. Packer, J. (2000). "The original nature of the Lund recommendations on the effective participation of national minorities in public life". Helsinki monitor, 2, 4.

21. Puddington, A. \& Roylance, T. (2017). "Populists and Autocrats: The Dual Threat to Global Democracy", Freedom in the world 2017, Freedom House. http: //freedomhouse.org/report/freedom-world/freedom-world-2017. 
22. "Syrie : la politique cynique et brutale de l'impérialisme". Lutte De Classe. No. 182. www.union-communiste.org/.../syrie-la-politiquecynique-et-brutale

23. Théron, J. P. \& Mourgeon, J. (1979). Libertés publiques. Paris: P.U.F.

24. The Economist Intelligence Unit's Democracy Index (2019, January 8): The retreat of global democracy stopped in 2018.

25. Titilayo, O. (2006). "Democracy and good governance, peace and conflict", http: www.tigweb.org 